\title{
Statistical Optimization of Fermentation Process Parameters by Taguchi Orthogonal Array Design for Improved Bioethanol Production
}

\author{
Saprativ P. Das, Debasish Das, and Arun Goyal \\ Department of Biotechnology, Indian Institute of Technology Guwahati, Guwahati, Assam 781 039, India \\ Correspondence should be addressed to Debasish Das; debasishd@iitg.ernet.in and Arun Goyal; arungoyl@iitg.ernet.in
}

Received 31 March 2013; Accepted 10 October 2013; Published 14 January 2014

Academic Editors: A. Ficarella, A. W. Mohammad, B. Moreno, and C. Mortalò

Copyright (C) 2014 Saprativ P. Das et al. This is an open access article distributed under the Creative Commons Attribution License, which permits unrestricted use, distribution, and reproduction in any medium, provided the original work is properly cited.

\begin{abstract}
The statistical optimization of different fermentation process parameters in SSF of mixed MAA and organosolv pretreated 1\% (w $\mathrm{v}^{-1}$ ) wild grass, namely, recombinant Clostridium thermocellum hydrolytic enzymes' volume (GH5 cellulase, GH43 hemicellulase), fermentative microbes' inoculum volume (Saccharomyces cerevisiae, Candida shehatae), $\mathrm{pH}$, and temperature, was accomplished by Taguchi orthogonal array design. The optimized parameters in $100 \mathrm{~mL}$ of fermentation medium were $\left(\%, \mathrm{v} \mathrm{v}^{-1}\right)$ as follows: 1.0 , recombinant GH5 cellulase $\left(5.7 \mathrm{mg}^{-1}, 0.45 \mathrm{mg} \mathrm{mL}^{-1}\right) ; 2.0$, recombinant GH43 hemicellulase $\left(3.7 \mathrm{U} \mathrm{mg}{ }^{-1}, 0.32 \mathrm{mg} \mathrm{mL}^{-1}\right) ; 1.5, S$. cerevisiae $\left(3.9 \times 10^{8}\right.$ cells $\left.\mathrm{mL}^{-1}\right) ; 0.25$, C. shehatae $\left(2.7 \times 10^{7}\right.$ cells $\left.\mathrm{mL}^{-1}\right) ; \mathrm{pH}, 4.3$; and temperature, $35^{\circ} \mathrm{C}$. $\mathrm{pH}$ with $p$-value 0.001 was found to be the most significant factor affecting SSF. The ethanol titre obtained in Taguchi optimized shake flask SSF was $2.0 \mathrm{~g} \mathrm{~L}{ }^{-1}$ implying a 1.3-fold increase as compared to ethanol titre of $1.5 \mathrm{~g} \mathrm{~L}^{-1}$ in unoptimized shake flask SSF. A 1.5-fold gain in ethanol titre $\left(3.1 \mathrm{~g} \mathrm{~L}^{-1}\right)$ was obtained with the same substrate concentration in lab scale bioreactor on scaling up the shake flask SSF with Taguchi optimized process parameters.
\end{abstract}

\section{Introduction}

Cost-effective fermentation of lignocellulosic hydrolysate to a value-added product, bioethanol, necessitates the conspicuous enhancement in the activities of various hydrolytic enzymes along with efficient mixed sugar utilization by various fermentative microbes [1]. Simultaneous saccharification and fermentation (SSF) is a single step combination of enzymatic hydrolysis of complex polysaccharides with concurrent fermentation of derived monosaccharides to ethanol [2]. The northeast part of India has a wide abundance of lignocellulosic substrate, namely, wild grass (Achnatherum hymenoides), rich in cellulose and hemicellulose [3]. As compared to the commercially employed hydrolytic enzyme of the corresponding Trichoderma system, the cellulosome of the anaerobic thermophilic bacterium, Clostridium thermocellum, exhibits a 50-fold higher specific activity against crystalline cellulose [4]. The advancement in molecular biology has familiarized new area of enzyme production in transformed cells with overexpression and their subsequent use for the breakdown of structural carbohydrates, namely, cellulose and hemicellulose, into simple sugars $[3,5]$.

According to CAZy database, glycoside hydrolase family 5 (GH5) exhibits activities of chitosanase (EC 3.2.1.132), cellulase (EC 3.2.1.4), glucan 1, 3- $\beta$-glucosidase (EC 3.2.1.58), and licheninase (EC 3.2.1.73) whereas glycoside hydrolase family 43 displays $\beta$-xylosidase (EC 3.2.1.37), $\alpha$-Larabinofuranosidase (EC 3.2.1.55), and xylanase (EC 3.2.1.8) activities. A number of available pretreatment techniques are used for liberating the cellulosic and hemicellulosic components from the lignin moieties and in turn rendering the accessibility to a better hydrolysis step [6]. Saccharomyces cerevisiae has the inherent ability to utilize hexose sugars from the breakdown of cellulose, considerable product tolerance, and resistance to metabolic inhibitions in ethanol production [7]. Xylitol dehydrogenase and xylose reductase are the prime enzymes of Candida shehatae that enable it to utilize pentose sugars from hemicellulose degradation for ethanol production [8]. 
Temperature, $\mathrm{pH}$, hydrolytic enzyme volume, and fermentative microbe's inoculum volume are the process parameters that play a vital role in lignocellulosic ethanol production [9]. The performance of multiple experiments by analyzing one variable at a time (OVAT) approach is time consuming and laborious for identifying various independent variables with their effects [10]. Statistically based experimental designs, namely, Plackett-Burman design, BoxBehnken design, and Taguchi orthogonal array design, summarize the collection and sorting of variables to be taken for consideration, determine the variable amount, and analyze the variable at different parameters and, finally, the effect of variable error. Better quality at low cost is the main aim for generation of Taguchi design of experiments (DOE) approaches to maximize robustness of products and processes [11]. Taguchi experimental design is a fast and considerable way of optimization conferring remarkable outcome in simultaneous study of many factors, making its mark in quality products supplemented with better process performance, and rendering high yield and better stability $[12,13]$. The basic principle involved is the encompassment of large experimental data as orthogonal (unbiased) array in determining the effect of various factors which govern the reaction happening, ensuing in experimental error reduction with improved producibility (efficiency) of experimental outcome. Taguchi design established the importance of statistically aligned experiments in speculating the settings of product (and/or processes) on various parameters $[14,15]$.

The current study emphasizes the Taguchi optimization of different fermentation process parameters such as mixed recombinant enzymes' volume (GH5 cellulase, GH43 hemicellulase), mixed cultures' inoculum volume (S. cerevisiae, C. shehatae), $\mathrm{pH}$, and temperature on bioethanol production from mixed pretreated wild grass with subsequent validation of the model at shake flask level and scale-up in a bioreactor.

\section{Materials and Methods}

2.1. Reagents, Chemicals, and Substrate. Carboxy methyl cellulose (CMC) and rye arabinoxylan were purchased from Sigma Aldrich (St. Louis, USA). The analytical grade reagents and chemicals, namely, LB medium, ampicillin, kanamycin, sodium acetate, glucose, yeast extract, peptone, potassium dichromate $\left(\mathrm{K}_{2} \mathrm{Cr}_{2} \mathrm{O}_{7}\right)$, sodium carbonate, sodium bicarbonate, sodium potassium tartrate, sodium sulphate, copper sulphate, ammonium molybdate, sodium arsenate, phosphoric acid, and ethanol, were purchased from Merck and Himedia Pvt. Ltd., India. Coomassie brilliant blue G-250 was purchased from Amresco LLC, USA. Lignocellulosic substrate wild grass (Achnatherum hymenoides) was collected from the campus of Indian Institute of Technology Guwahati, India. The substrate was washed with water thrice for the removal of adhered dust particles, dried, and finally grinded to $1 \mathrm{~mm}$ mesh size.

2.2. Microorganisms and Culturing Conditions. The recombinant E. coli BL21 (DE3) cells harbouring family 5 glycoside hydrolase (GH5) gene from Clostridium thermocellum were cloned in an expression vector pET-21a(+) and expressed earlier $[16,17]$. The recombinant GH5 cellulase is available commercially at NZY Tech, Lda, Lisbon, Portugal. The recombinant E. coli BL21 (DE3) pLysS cells transformed by family 43 glycoside hydrolase (GH43) gene from Clostridium thermocellum and cloned in $\mathrm{pET}-28 \mathrm{a}(+)$ expression vector were expressed earlier [3]. These cells were cast off as a source of recombinant GH43 hemicellulase. These E. coli BL21 cells were preserved in $\mathrm{LB}$ medium as glycerol stock at $-80^{\circ} \mathrm{C}$ in our laboratory at IIT Guwahati.

The fermentative microbes, Saccharomyces cerevisiae (NCIM no. 3215), and Candida shehatae (NCIM no. 3500), procured from National Chemical Laboratory, Pune, India, were maintained independently at $4^{\circ} \mathrm{C}$ on $5 \mathrm{~mL}$ of Malt extract glucose yeast extract peptone (MGYP) slants containing malt extract $\left(0.3 \mathrm{~g} 100 \mathrm{~mL}^{-1}\right)$, glucose $\left(1 \mathrm{~g} 100 \mathrm{~mL}^{-1}\right)$, yeast

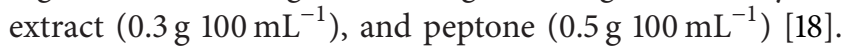
One loopful from these slant cultures was further introduced into $50 \mathrm{~mL}$ of glucose yeast extract (GYE) medium in two separate $100 \mathrm{~mL}$ Erlenmeyer flasks containing glucose $(1 \mathrm{~g}$

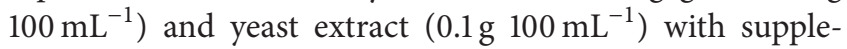
mentation of $\mathrm{KH}_{2} \mathrm{PO}_{4}\left(0.1 \mathrm{~g} 100 \mathrm{~mL}^{-1}\right),\left(\mathrm{NH}_{4}\right)_{2} \mathrm{SO}_{4}(0.5 \mathrm{~g}$ $\left.100 \mathrm{~mL}^{-1}\right)$, and $\mathrm{MgSO}_{4} \cdot 7 \mathrm{H}_{2} \mathrm{O}\left(0.05 \mathrm{~g} 100 \mathrm{~mL}^{-1}\right)$. They were incubated at $30^{\circ} \mathrm{C}$ and $120 \mathrm{rpm}$ for $48 \mathrm{~h}$ prior to inoculation into fermentation media. The aliquots measuring $1 \mathrm{~mL}$ from each of the actively growing cultures of $S$. cerevisiae $(3.9 \times$ $10^{8}$ cells $\left.\mathrm{mL}^{-1}\right)$ and $C$. shehatae $\left(2.7 \times 10^{7}\right.$ cells $\left.\mathrm{mL}^{-1}\right)$ were aseptically inoculated to $100 \mathrm{~mL}$ fermentation medium. The cell count of the actively growing $S$. cerevisiae and C. shehatae was measured using a haemocytometer.

\subsection{Production of Recombinant Cellulase (GH5) and Hemi-} cellulase (GH43). The recombinant GH5 cellulase production was initiated by inoculating $50 \mu \mathrm{L}$ of the E. coli BL21 (DE3) culture from glycerol stocks into $5 \mathrm{~mL}$ of LB medium containing $100 \mu \mathrm{g} \mathrm{mL}^{-1}$ ampicillin with incubation at $37^{\circ} \mathrm{C}$ and $180 \mathrm{rpm}$ for $16 \mathrm{~h}$. One percent $\left(\mathrm{vv}^{-1}\right)$ of the culture inoculum was transferred aseptically to $200 \mathrm{~mL}$ of $\mathrm{LB}$ medium in $500 \mathrm{~mL}$ flask containing $100 \mu \mathrm{g} \mathrm{mL}^{-1}$ ampicillin and was incubated at $37^{\circ} \mathrm{C}$ and $180 \mathrm{rpm}$ till the culture reached the midexponential phase $\left(A_{600 \mathrm{~nm}} 0.6\right)$. This midexponential phase culture was induced with isopropyl- $\beta$ D-thiogalactopyranoside (IPTG) (1 mM final concentration) followed by further $8 \mathrm{~h}$ incubation for overexpression of recombinant protein [16]. $50 \mu \mathrm{g} \mathrm{mL}^{-1}$ kanamycin was used as a selective marker for E. coli BL21 (DE3) plysS cells containing GH43 hemicellulase [3]. Similar production process was employed for GH43 hemicellulase as followed for GH5 cellulase, except that the incubation period was $24^{\circ} \mathrm{C}$, $180 \mathrm{rpm}$, and $24 \mathrm{~h}$ for overexpression of protein after IPTG (1 mM final concentration) was added. The overexpressed $E$. coli cells ( $\mathrm{GH} 5$ or $\mathrm{GH} 43)$ collected by centrifugation $\left(4^{\circ} \mathrm{C}\right.$, $8,510 \mathrm{~g}$, and $30 \mathrm{~min}$ ) were resuspended in $50 \mathrm{mM}$ sodium phosphate buffer ( $\mathrm{pH}$ 7.0). Each of the resuspended cell pellets was subjected to sonication (SONICS, Vibra Cell, Newtown, CT, USA) in an ice-bath separately for $15 \mathrm{~min}$ with further centrifugation $\left(4^{\circ} \mathrm{C}, 19,650 \mathrm{~g}\right.$, and $\left.30 \mathrm{~min}\right)$. The 
TABLE 1: Factor (parameter) and levels in Taguchi experimental design for shake flask SSF process employing mixed pretreated $1 \%\left(\mathrm{w} \mathrm{v}^{-1}\right)$ wild grass at $120 \mathrm{rpm}$.

\begin{tabular}{|c|c|c|c|c|c|}
\hline Factor/parameter & & & Levels & & \\
\hline Recombinant GH5 cellulase* $^{*}\left(5.7 \mathrm{U} \mathrm{mg}^{-1}, 0.45 \mathrm{mg} \mathrm{mL}^{-1}\right)$ & 0.25 & 0.5 & 1.0 & 1.5 & 2.0 \\
\hline Recombinant GH43 hemicellulase* $\left(3.7 \mathrm{U} \mathrm{mg}^{-1}, 0.32 \mathrm{mg} \mathrm{mL}^{-1}\right)$ & 0.25 & 0.5 & 1.0 & 1.5 & 2.0 \\
\hline S. cerevisiae ${ }^{*}\left(3.6 \times 10^{8}\right.$ cells $\left.\mathrm{mL}^{-1}\right)$ & 0.25 & 0.5 & 1.0 & 1.5 & 2.0 \\
\hline C. shehatae $^{*}\left(2.1 \times 10^{8}\right.$ cells $\left.\mathrm{mL}^{-1}\right)$ & 0.25 & 0.5 & 1.0 & 1.5 & 2.0 \\
\hline $\mathrm{pH}$ & 3 & 4.3 & 5.0 & 5.5 & 6 \\
\hline Temperature $\left({ }^{\circ} \mathrm{C}\right)$ & 26 & 28 & 30 & 33 & 35 \\
\hline
\end{tabular}

${ }^{*}$ The values of levels in $\left(\%, \mathrm{vv}^{-1}\right)$.

two recombinant enzymes, GH5 cellulase and GH43 hemicellulase, were expressed as soluble proteins. The cell free supernatant obtained was employed as the enzyme source for SSF experiments [16].

2.4. Mixed Pretreatment Strategy. Microwave-assisted alkali (MAA) pretreatment loosens the compact structure of cellulose and aids in its hydrolysis to glucose [19]. Organosolv pretreatment with the assistance of different organic acids benefits in relaxing the complex hemicellulose for its efficient hydrolysis to xylose [20]. Owing to the substantial quantities of cellulose and hemicellulose in wild grass, the lignocellulosic substrate was subjected to mixed MAA and organosolv pretreatment strategy.

2.5. Microwave-Assisted Alkali (MAA) Pretreatment. One gram (dry powder) of wild grass (A. hymenoides) was suspended in $8 \mathrm{~mL}$ of $1 \%\left(\mathrm{vv}^{-1}\right)$ sodium hydroxide aqueous solution in a $100 \mathrm{~mL}$ beaker. The beaker was positioned at the centre of a rotating circular glass plate in a domestic microwave oven at $900 \mathrm{~W}$ for $25 \mathrm{~min}$ [19]. The substrate filtered through muslin cloth was further subjected to organosolv pretreatment.

2.6. Organosolv Pretreatment. The microwave-assisted alkali (MAA) pretreated and filtered wild grass was further subjected to $20 \mathrm{~mL}$ of $\left(70: 30 \mathrm{vv}^{-1}\right)$ ethanol : water mixture containing $1 \%\left(\mathrm{vv}^{-1}\right)$ of sulphuric acid, hydrochloric acid, acetic acid, and phosphoric acid ( $1 \mathrm{~mL}$ each) at $70^{\circ} \mathrm{C}$ for $1 \mathrm{~h}$ [20]. The substrate was then washed with two ethanolic extracts: $95 \%\left(\mathrm{v} \mathrm{v}^{-1}\right)$ ethanol at $60^{\circ} \mathrm{C}$ for $4 \mathrm{~h}$ and $70 \%\left(\mathrm{vv}^{-1}\right)$ ethanol at $30^{\circ} \mathrm{C}$ for $1 \mathrm{~h}$. The substrate residue was further treated with $4 \%$ $\left(\mathrm{v} \mathrm{v}^{-1}\right)$ hydrogen peroxide at $45^{\circ} \mathrm{C}$ for $16 \mathrm{~h}$. The final washing was done with $70 \%$ ethanol at $30^{\circ} \mathrm{C}$ for $1 \mathrm{~h}$ [20]. The mixed pretreated substrate was subsequently subjected to enzymatic hydrolysis.

2.7. Simultaneous Saccharification and Fermentation (SSF) Process of Mixed Pretreated 1\% $\left(w v^{-1}\right)$ Wild Grass at Shake Flask Level. One percent $\left(\mathrm{wv}^{-1}\right)$ of the mixed microwave-assisted alkali (MAA) and organosolv pretreated wild grass (A. hymenoides) was autoclaved in $250 \mathrm{~mL}$ Erlenmeyer flask encompassing $100 \mathrm{~mL}$ working volume of $20 \mathrm{mM}$ sodium acetate buffer ( $\mathrm{pH}$ 5.0) supplemented with $\left(0.1 \%, \mathrm{w} \mathrm{v}^{-1}\right)$ each of the yeast extract and peptone. Then, $0.5 \mathrm{~mL}$ of each crude recombinant cellulase (GH5) (5.7 $\mathrm{U} \mathrm{mg}^{-1}, 0.45 \mathrm{mg} \mathrm{mL}^{-1}$ ) and recombinant hemicellulase (GH43) (3.7 $\mathrm{U} \mathrm{mg}^{-1}, 0.32 \mathrm{mg} \mathrm{mL}^{-1}$ ) was added as the mixed enzymatic consortium for hydrolysis. At the same time, $0.5 \mathrm{~mL}$ of each $S$. cerevisiae $\left(3.9 \times 10^{8}\right.$ cells $\left.\mathrm{mL}^{-1}\right)$ and $C$. shehatae $\left(2.7 \times 10^{7}\right.$ cells $\left.\mathrm{mL}^{-1}\right)$ inoculum was added for fermentation. The flasks were kept at $30^{\circ} \mathrm{C}$ and $120 \mathrm{rpm}$ for $72 \mathrm{~h}$ and the sample was collected at every $6 \mathrm{~h}$ interval. The monitoring of SSF dynamic profile was done with the measurement of the cell OD $\left(\mathrm{A}_{600 \mathrm{~nm}}\right)$, reducing sugar $\left(\mathrm{g} \mathrm{L}^{-1}\right)$, ethanol concentration $\left(\mathrm{g} \mathrm{L}^{-1}\right)$, and specific activity $\left(\mathrm{U} \mathrm{mg}^{-1}\right)$.

\subsection{Optimization of Process Parameters of}

Simultaneous Saccharification and Fermentation (SSF)

Involving Mixed Pretreated Wild Grass at Shake

Flask Level by Taguchi Method

2.8.1. Statistical Optimization Using Taguchi Orthogonal Array Design. Taguchi experimental design matrix, a standard orthogonal array $\mathrm{L}_{25}\left(6_{5}\right)$, was used to examine six factors, namely, recombinant $\mathrm{GH} 5$ cellulase $\left(5.7 \mathrm{U} \mathrm{mg}^{-1}\right.$, $0.45 \mathrm{mg} \mathrm{mL}^{-1}$ ) volume $(\mathrm{mL})$, recombinant GH43 hemicellulase $\left(3.7 \mathrm{U} \mathrm{mg}^{-1}, 0.32 \mathrm{mg} \mathrm{mL}^{-1}\right)$ volume $(\mathrm{mL}), S$. cerevisiae $\left(3.9 \times 10^{8}\right.$ cells $\left.\mathrm{mL}^{-1}\right)$ inoculum volume $(\mathrm{mL}), C$. shehatae $\left(2.7 \times 10^{7}\right.$ cells $\left.\mathrm{mL}^{-1}\right)$ inoculum volume $(\mathrm{mL}), \mathrm{pH}$, and temperature $\left({ }^{\circ} \mathrm{C}\right)$ in five levels, namely, Level 1 to Level 5 (Table 1), in SSF experiments involving mixed pretreated $1 \%$ $\left(\mathrm{w} \mathrm{v}^{-1}\right)$ wild grass at shake flask level. The lower and upper levels of optimized factors were selected on the basis of the suitable conditions for the active functioning of the recombinant hydrolytic enzymes and the desired growth of the fermentative microbes for efficient bioethanol production. The $\mathrm{L}$ and the subscript (25) represent the Latin square and the number of experimental runs, respectively. The levels of the factors studied and the layout of the $\mathrm{L}_{25}$ Taguchi's orthogonal array are represented in Tables 1 and 2. Each of the twenty-five simultaneous saccharification and fermentation (SSF) experiments denoted by "runs" was carried out as per the defined values of six different parameters in five levels (Table 2). All the SSF experiments were carried out in $100 \mathrm{~mL}$ of fermentation media at $120 \mathrm{rpm}$ for $72 \mathrm{~h}$ at varying 
TABLE 2: Matrix layout of the $\mathrm{L}_{25}$ Taguchi orthogonal array design.

\begin{tabular}{|c|c|c|c|c|c|c|}
\hline Run/expt. no. & $\begin{array}{l}\text { Recombinant GH5 } \\
\text { cellulase* }^{*}\end{array}$ & $\begin{array}{l}\text { Recombinant GH43 } \\
\text { hemicellulase* }^{*}\end{array}$ & S. cerevisiae ${ }^{*}$ & C. shehatae* & $\mathrm{pH}$ & Temperature \\
\hline 1 & 0.25 & 1 & 1 & 1 & 5 & 30 \\
\hline 2 & 0.5 & 1.5 & 2 & 0.25 & 4.3 & 30 \\
\hline 3 & 1 & 2 & 0.5 & 1.5 & 3 & 30 \\
\hline 4 & 1.5 & 0.25 & 1.5 & 0.5 & 6 & 30 \\
\hline 5 & 2 & 0.5 & 0.25 & 2 & 5.5 & 30 \\
\hline 6 & 0.25 & 0.25 & 0.25 & 0.25 & 3 & 26 \\
\hline 7 & 0.5 & 0.5 & 1 & 1.5 & 6 & 26 \\
\hline 8 & 1 & 1 & 2 & 0.5 & 5.5 & 26 \\
\hline 9 & 1.5 & 1.5 & 0.5 & 2 & 5 & 26 \\
\hline 10 & 2 & 2 & 1.5 & 1 & 4.3 & 26 \\
\hline 11 & 2 & 0.25 & 2 & 1.5 & 5 & 28 \\
\hline 12 & 1.5 & 2 & 1 & 0.25 & 5.5 & 28 \\
\hline 13 & 1 & 1.5 & 0.25 & 1 & 6 & 28 \\
\hline 14 & 0.5 & 1 & 1.5 & 2 & 3 & 28 \\
\hline 15 & 0.25 & 0.5 & 0.5 & 0.5 & 4.3 & 28 \\
\hline 16 & 0.25 & 1.5 & 1.5 & 1.5 & 5.5 & 33 \\
\hline 17 & 0.5 & 2 & 0.25 & 0.5 & 5 & 33 \\
\hline 18 & 1 & 0.25 & 1 & 2 & 4.3 & 33 \\
\hline 19 & 1.5 & 0.5 & 2 & 1 & 3 & 33 \\
\hline 20 & 2 & 1 & 0.5 & 0.25 & 6 & 33 \\
\hline 21 & 0.25 & 2 & 2 & 2 & 6 & 35 \\
\hline 22 & 0.5 & 0.25 & 0.5 & 1 & 5.5 & 35 \\
\hline 23 & 1 & 0.5 & 1.5 & 0.25 & 5 & 35 \\
\hline 24 & 1.5 & 1 & 0.25 & 1.5 & 4.3 & 35 \\
\hline 25 & 2 & 1.5 & 1 & 0.5 & 3 & 35 \\
\hline
\end{tabular}

${ }^{*}$ The values of levels in $\left(\%, \mathrm{vv}^{-1}\right)$.

temperatures (Table 1) with sample collection at every $6 \mathrm{~h}$ interval.

\subsubsection{Analysis of the Taguchi Orthogonal Array Experiments} (Runs). The MINITAB statistical software package (Design Expert, version 8.0) was used to determine the outcomes of the fermentation runs. The signal-to-noise ratio $(S / N)$, which is the logarithmic function of desired output, served as objective function for optimization.

For each run, $S / N$ ratio corresponding to larger-thebetter objective function was computed using relation in

$$
\frac{S}{N}=-10 \log _{10} \frac{1}{n} \sum_{i=1}^{n} \frac{1}{y_{i}^{2}}
$$

where " $y_{i}$ " is the signal and " $n$ " is the number of repetitions in each experiment.

The response values in terms of ethanol titre $\left(\%, \mathrm{vv}^{-1}\right)$ and $S / N$ ratios of Taguchi experimental design in 25 runs were analysed to extract independently the main effects of the factors; the analysis of variance technique was then applied to determine which factors were statistically significant. The controlling factors were identified, with the magnitude of the effects qualified and the statistically significant effects determined. Accordingly, the optimal conditions were determined by combining the levels of factors that had the highest main effect value. The analysis of variance (ANOVA) for the responses of ethanol production was carried out according to the factors' contribution by the Taguchi method. The factors in the experimental design considered to be statistically significant at $95 \%$ confidence limit were used to determine the ratio $(F)$ and the $p$-value $(p<0.05)$.

2.8.3. Validation of the Experimental Model. The model was validated by performing the SSF trial employing Taguchi optimized fermentation process parameters on mixed pretreated $1 \%\left(\mathrm{w} \mathrm{v}^{-1}\right)$ wild grass in $100 \mathrm{~mL}$ of fermentation medium. The best fermentation process parameters comprised $1.0 \mathrm{~mL}$ of recombinant $\mathrm{GH} 5$ cellulase $\left(5.7 \mathrm{U} \mathrm{mg}^{-1}\right.$, $0.45 \mathrm{mg} \mathrm{mL}^{-1}$ ), $2.0 \mathrm{~mL}$ of recombinant $\mathrm{GH} 43$ hemicellulase $\left(3.7 \mathrm{U} \mathrm{mg}^{-1}, 0.32 \mathrm{mg} \mathrm{mL}^{-1}\right), 1.5 \mathrm{~mL}$ of $S$. cerevisiae $(3.9 \times$ $10^{8}$ cells $\left.\mathrm{mL}^{-1}\right), 0.25 \mathrm{~mL}$ of $C$. shehatae $\left(2.7 \times 10^{7}\right.$ cells $\left.\mathrm{mL}^{-1}\right)$, $\mathrm{pH}$ of 4.3 , and temperature of $35^{\circ} \mathrm{C}$. The fermentation was carried out at $120 \mathrm{rpm}$ for $72 \mathrm{~h}$ with $6 \mathrm{~h}$ sample collection interval. The validation of the experimental model was executed by determining the ethanol titre $\left(\%, \mathrm{vv}^{-1}\right)$. 
2.8.4. Scale-Up of Taguchi Optimized Simultaneous Saccharification and Fermentation (SSF) Process Parameters Involving Mixed Pretreated 1\% $\left(w v^{-1}\right)$ Wild Grass at Bioreactor Level. The Taguchi optimized SSF process parameters involving mixed pretreated $1 \%\left(\mathrm{wv}^{-1}\right)$ wild grass were scaled up to $1 \mathrm{~L}$ in a $2 \mathrm{~L}$ lab scale fermentor (Applikon, model Bio Console ADI 1025, Holland). $10 \mathrm{~g} \mathrm{~L}^{-1}$ of mixed MAA and organosolv pretreated wild grass (A. hymenoides) was used as substrate for bioreactor SSF experiments. $10 \mathrm{~mL}$ of isolated crude recombinant $\mathrm{GH} 5$ cellulase $\left(5.7 \mathrm{U} \mathrm{mg}^{-1}, 0.45 \mathrm{mg} \mathrm{mL}^{-1}\right)$ along with $20 \mathrm{~mL}$ of recombinant $\mathrm{GH} 43$ hemicellulase $\left(3.7 \mathrm{U} \mathrm{mg}^{-1}\right.$, $0.32 \mathrm{mg} \mathrm{mL}^{-1}$ ) was employed for saccharification. $15 \mathrm{~mL}$ of $S$. cerevisiae $\left(3.9 \times 10^{8}\right.$ cells $\left.\mathrm{mL}^{-1}\right)$ and $2.5 \mathrm{~mL}$ of $C$. shehatae $(2.7$ $\times 10^{7}$ cells $\mathrm{mL}^{-1}$ ) were engaged for bioethanol production. The SSF was carried out at $35^{\circ} \mathrm{C}, \mathrm{pH} 4.3$, and agitation of $120 \mathrm{rpm}$. For the efficient growth of fermentative microbes, an aeration rate of $1 \mathrm{vvm}$ was controlled by a mass flow controller to maintain the dissolved oxygen (DO) level of minimum $40 \%$. Growth was observed at $600 \mathrm{~nm}$ using UVvisible spectrophotometer (Varian Cary50, Australia). The online process parameters, namely, temperature $\left({ }^{\circ} \mathrm{C}\right), \mathrm{pH}$, and stirring rate $(\mathrm{rpm})$, were noted for every $1 \mathrm{~min}$. The different parameters of cell $\mathrm{OD}\left(\mathrm{A}_{600 \mathrm{~nm}}\right)$, reducing sugar $\left(\mathrm{g} \mathrm{L}^{-1}\right)$, ethanol concentration $\left(\mathrm{g} \mathrm{L}^{-1}\right)$, and specific activity $\left(\mathrm{U} \mathrm{mg}^{-1}\right)$ were surveyed at $6 \mathrm{~h}$ fixed interval. The addition of $1 \mathrm{~N} \mathrm{HCl}$ and $1 \mathrm{~N} \mathrm{NaOH}$ to maintain the $\mathrm{pH}$ at 4.3 prohibited the $\mathrm{pH}$ excursions of the organism below the set point.

\subsection{Analytical Methods}

2.9.1. Estimation of Structural Carbohydrate. The structural carbohydrates like cellulose, hemicellulose, and lignin of untreated and pretreated wild grass were estimated by the standardized methods of NREL, USA [21]. $0.3 \mathrm{~g}$ of dry powdered substrate (untreated or pretreated) was mixed with $3 \mathrm{~mL}$ of $\mathrm{H}_{2} \mathrm{SO}_{4}(27 \mathrm{~N})$ and kept at $30^{\circ} \mathrm{C}$ for $1 \mathrm{~h}$. Then $84 \mathrm{~mL}$ of distilled water was added to lower down the concentration of $\mathrm{H}_{2} \mathrm{SO}_{4}$ to $1.5 \mathrm{~N}$. Then, the sample was autoclaved at $121^{\circ} \mathrm{C}$ for $1 \mathrm{~h}$. The substrate was cooled to room temperature and the biomass (untreated or pretreated) was filtered using a vacuum filtration unit. The residue weighed was lignin (acid insoluble lignin). The $\mathrm{pH}$ of the collected filtrate was neutralized by addition of $\mathrm{CaCO}_{3}(1 \mathrm{M})$. Finally, the filtrate was assessed for reducing sugar (glucose) and in turn cellulose was calculated ( $1 \mathrm{~g}$ cellulose $=1.1 \mathrm{~g}$ of glucose $)$. The remaining content was hemicellulose.

2.9.2. Recombinant GH5 Cellulase, GH43 Hemicellulase Assay, and Protein Content Determination. The recombinant GH5 cellulase assay was performed by incubating the enzyme $(10 \mu \mathrm{L})$ in a $100 \mu \mathrm{L}$ reaction mixture with $1 \%\left(\mathrm{w} \mathrm{v}^{-1}\right)$ final concentration of CMC in $20 \mathrm{mM}$ sodium acetate buffer $(\mathrm{pH} 4.3)$ at $50^{\circ} \mathrm{C}$ and $10 \mathrm{~min}$. The mixture was assessed for the released reducing sugar $[22,23]$. The released reducing sugar was used to determine the enzyme activity. The GH43 hemicellulase activity was tested by incubating $10 \mu \mathrm{L}$ of the recombinant enzyme in a $100 \mu \mathrm{L}$ reaction mixture with $1 \%$ $\left(\mathrm{w} \mathrm{v}^{-1}\right)$ final concentration of rye arabinoxylan in $100 \mathrm{mM}$ sodium acetate buffer $(\mathrm{pH} 5.4)$ at $50^{\circ} \mathrm{C}$ for $10 \mathrm{~min}$. The absorbance was measured using a UV-visible spectrophotometer (Perkin Elmer, Model lambda-45) at $500 \mathrm{~nm}$ against a blank with D-glucose or L-arabinose as standard. One unit (U) of cellulase activity is defined as the amount of enzyme that liberates $1 \mu$ mole of reducing sugar (glucose) per min under the above assay conditions. On the other hand, one unit $(\mathrm{U})$ of hemicellulase activity is defined as the amount of enzyme that releases $1 \mu$ mole of reducing sugar (arabinose) per min under the above assay conditions. The concentration of protein was detected by mixing the enzyme $(10 \mu \mathrm{L})$ with distilled water $(90 \mu \mathrm{L})$ in a total reaction volume $(100 \mu \mathrm{L})$ with final addition of $1 \mathrm{~mL}$ Bradford reagent [24]. The reaction mixture was upheld at $25^{\circ} \mathrm{C}$ for $20 \mathrm{~min}$ and OD was determined using a UV-visible spectrophotometer (Perkin Elmer, Model lambda-45) at $595 \mathrm{~nm}$. A BSA standard curve was used to determine the protein concentration.

2.9.3. Ethanol Content Determination by Gas Chromatography and Dichromate Method. The ethanol fraction in fermentation broth was determined by gas chromatography furnished with flame ionization detector (GC-FID, Varian 450) and Porapak (Hayesep) Q packed column $(3.0 \mathrm{~m} \times 2.0 \mathrm{~mm}$ i.d., $80-100$ mesh, Varian). A constant flow rate $\left(55 \mathrm{~cm}^{3} \mathrm{~min}^{-1}\right)$ of nitrogen was used as the carrier gas with the oven temperature kept constant at $150^{\circ} \mathrm{C}$ for 20 min as per Bandaru et al., 2006 [25]. Both the injector and detector temperatures were maintained at $170^{\circ} \mathrm{C}$. The injection volume used for ethanol analysis was $1 \mu \mathrm{L}$.

The dichromate method was also employed to detect the ethanol content by its conversion to acid following dichromatic reaction [26]. The cell free supernatant of fermentation broth $(1 \mathrm{~mL})$ was mixed with $0.115 \mathrm{M} \mathrm{K}_{2} \mathrm{Cr}_{2} \mathrm{O}_{7}(2 \mathrm{~mL})$ with final addition of $9 \mathrm{~mL}$ distilled water. The $12 \mathrm{~mL}$ reaction mixture was kept for $10 \mathrm{~min}$ in a boiling water bath. Finally, the absorbance of the cooled sample was measured against a blank of potassium dichromate $\left(\mathrm{K}_{2} \mathrm{Cr}_{2} \mathrm{O}_{7}\right)$ as standard using a UV-visible spectrophotometer (Perkin Elmer, Model lambda-45) at $600 \mathrm{~nm}$.

The ethanol yield ( $g$ of ethanol $g$ of substrate ${ }^{-1}$ ) was obtained by dividing the maximum ethanol concentration $\left(\mathrm{g} \mathrm{L}^{-1}\right)$ attained in SSF experiments with initial cellulose and hemicellulose concentration $\left(\mathrm{g} \mathrm{L}^{-1}\right)$ of the pretreated wild grass (lignin was not taken into account). When these ethanol yields are compared with the theoretical $0.51 \mathrm{~g}$ ethanol $/ \mathrm{g}$ of sugar (glucose or xylose) yield, since the residual cellulose and hemicellulose contents after fermentation were not determined in our SSF studies, the amount of cellulose and hemicellulose consumed could not be calculated. Similar method for calculation of ethanol yield has been reported earlier [27].

\section{Results and Discussion}

The improved saccharification of cellulosic and hemicellulosic components of lignocellulosic biomass by competent hydrolytic enzymes with simultaneous consumption of 
TABLE 3: Comparison of unoptimized and Taguchi optimized SSF combinations with mixed pretreated wild grass.

\begin{tabular}{|c|c|c|c|c|}
\hline SSF combination & $\begin{array}{c}\text { Substrate concentration } \\
\left(\%, \mathrm{w} \mathrm{v}^{-1}\right) \text { and mode } \\
\text { of SSF }\end{array}$ & $\begin{array}{l}\text { Reducing sugar* } \\
\qquad\left(\mathrm{g} \mathrm{L}^{-1}\right)\end{array}$ & $\begin{array}{l}\text { Ethanol yield } \\
\text { ( } \mathrm{g} \text { of ethanol } \mathrm{g} \text { of } \\
\text { pretreated substrate }{ }^{-1} \text { ) }\end{array}$ & $\begin{array}{c}\text { Ethanol titre } \\
\qquad\left(\mathrm{g} \mathrm{L}^{-1}\right)\end{array}$ \\
\hline $\begin{array}{l}\mathrm{GH} 5+\mathrm{GH} 43+\text { S. cerevisiae }+ \text { C. shehatae } \\
\text { (unoptimized) }\end{array}$ & $\begin{array}{c}1 \% \\
\text { shake flask }\end{array}$ & $1.70 \pm 0.09$ & 0.228 & $1.50 \pm 0.06$ \\
\hline $\begin{array}{l}\text { GH5 + GH } 43+\text { S. cerevisiae }+ \text { C. shehatae } \\
\text { (Taguchi optimized) }\end{array}$ & $\begin{array}{c}1 \% \\
\text { shake flask }\end{array}$ & $2.31 \pm 0.05$ & 0.304 & $2.0 \pm 0.04$ \\
\hline $\begin{array}{l}\text { GH5 + GH } 43+\text { S. cerevisiae }+ \text { C. shehatae } \\
\text { (Taguchi optimized) }\end{array}$ & $\begin{array}{c}1 \% \\
\text { bioreactor }\end{array}$ & $4.02 \pm 0.03$ & 0.472 & $3.10 \pm 0.07$ \\
\hline
\end{tabular}

* The values correspond to the maximum reducing sugar and maximum ethanol at a particular time; values are mean \pm SE $(n=3)$.

monomeric sugars by fermentative microbes is the technoeconomic viability of an efficient SSF process. The structural carbohydrates determination of wild grass (A. hymenoides) revealed greater amount of cellulose (50.09 $\left.\pm 0.32 \%, \mathrm{w} \mathrm{w}^{-1}\right)$ followed by hemicellulose $\left(29.9 \pm 0.67 \% \mathrm{w} \mathrm{w}^{-1}\right)$, suggesting wild grass as the suitable candidate for SSF based bioethanol production. The microwave-assisted alkali (MAA) pretreatment is reported to increase cellulose hydrolysis [19] and the organosolv pretreatment is more effective for hemicellulosic content breakdown of agroresidues [20]. The carbohydrate composition of wild grass after mixed pretreatment revealed cellulose $\left(43.32 \pm 0.51 \%, \mathrm{w} \mathrm{w}^{-1}\right)$ and hemicellulose $(22.35 \pm$ $\left.0.48 \% \mathrm{w} \mathrm{w}^{-1}\right)$. In the current study, the desired volume of recombinant $C$. thermocellum mixed enzymes for the production of simple sugars and the inoculum volume of mixed fermentative microbes along with other process parameters for bioethanol production from mixed MAA and organosolv pretreated wild grass were optimized by Taguchi statistical design in shake flask and scaled up in bioreactor.

\subsection{Unoptimized Simultaneous Saccharification and Fermen-} tation (SSF) Process of Mixed Pretreated $1 \%\left(w v^{-1}\right)$ Wild Grass at Shake Flask Level. The dynamic profile of SSF involving unoptimized process parameters for ethanol production from mixed pretreated $1 \%\left(\mathrm{w} \mathrm{v}^{-1}\right)$ wild grass at shake flask level is represented in Figure 1. The mixed cultures of S. cerevisiae and C. shehatae exhibited negligible lag phase in their growth with steady increase till $66 \mathrm{~h}$ with slight decrease thereafter (Figure 1). The growth-associated ethanol formation began from $12 \mathrm{~h}$ of SSF with a gradual increase till $36 \mathrm{~h}$ after which a sharp rise was observed till $54 \mathrm{~h}$ (Figure 1). The maximum ethanol titre achieved was $1.50 \mathrm{~g} \mathrm{~L}^{-1}$ (Table 3, Figure 1) with a yield of 0.228 ( $\mathrm{g}$ of ethanol $\mathrm{g}$ of substrate ${ }^{-1}$ ). Thereafter, a decrease in ethanol production was witnessed. The initial phase of the SSF represented an accumulation of available sugars till $18 \mathrm{~h}$ with a gradual decline. The maximum reducing sugar concentration was $1.70 \mathrm{~g} \mathrm{~L}^{-1}$ (Figure 1). The activities of both the recombinant enzymes decreased with the progress in fermentation. The dynamic profile of only recombinant GH5 cellulase has been shown in Figure 1 as wild grass contains more cellulose. Interestingly, the microbial growth and ethanol production shared an inverse relationship with enzyme activities and, in turn, the reducing sugars released

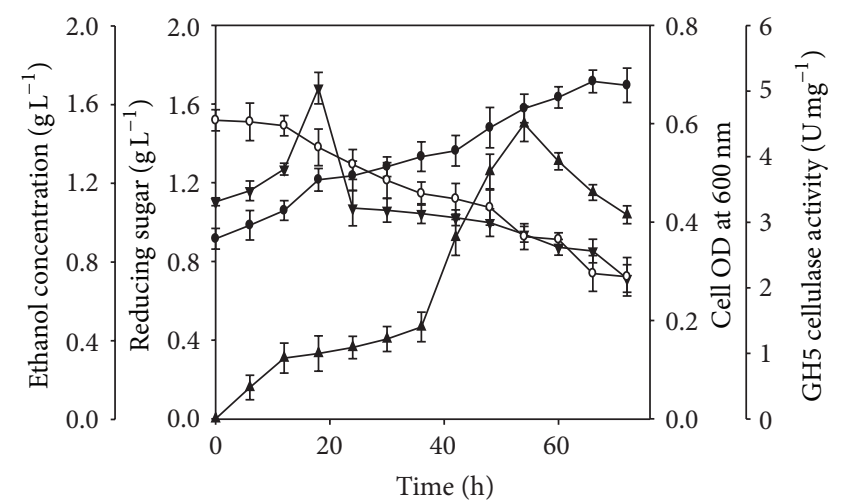

FIGURE 1: SSF profile of $1 \%\left(\mathrm{wv}^{-1}\right)$ mixed MAA and organosolv pretreated wild grass (Achnatherum hymenoides) using unoptimized fermentation process parameters, namely, recombinant cellulase (GH5), recombinant hemicellulase (GH43) along with S. cerevisiae, C. shehatae, $\mathrm{pH}$, and temperature at shake flask level showing variation of $(\bullet)$ cell OD measured at $600 \mathrm{~nm}$, (A) ethanol concentration $\left(\mathrm{g} \mathrm{L}^{-1}\right),(\boldsymbol{\nabla})$ reducing sugar $\left(\mathrm{g} \mathrm{L}^{-1}\right)$, and $(\mathrm{O})$ specific activity $\left(\mathrm{U} \mathrm{mg}^{-1}\right)$ of $\mathrm{GH} 5$ cellulase with time (h). Similar specific activity profiles were obtained for recombinant hemicellulase (GH43) (data not shown).

clearly demonstrating the fact of sugar utilization by the organisms for growth and ethanol formation (Figure 1).

\subsection{Optimization of Process Parameters of Simultaneous} Saccharification and Fermentation (SSF) Involving Mixed Pretreated Wild Grass by Taguchi Method. Taguchi experimental design is a good positive option for the optimization of biotechnological processes. The fermentation process parameters, namely, temperature, $\mathrm{pH}$, hydrolytic enzyme volume, and fermentative microbe's inoculum volume, play an important role in lignocellulosic ethanol production [9]. In this case, the influence of 6 factors on the SSF process was tested by Taguchi experimental design in 25 runs (Tables 1 and 2). The response values in terms of ethanol titre $\left(\%, \mathrm{vv}^{-1}\right)$ and $S / N$ ratios of Taguchi experimental design in 25 runs, for the six factors, that is, recombinant GH5 cellulase volume, recombinant GH43 hemicellulase volume, $S$. cerevisiae inoculum volume, C. shehatae inoculum volume, $\mathrm{pH}$, and temperature $\left({ }^{\circ} \mathrm{C}\right)$, chosen for optimization of ethanol production by SSF process (Table 4), show the efficiency of 
TABLE 4: Response values and $S / N$ ratio of $\mathrm{L}_{25}$ Taguchi orthogonal array design.

\begin{tabular}{|c|c|c|}
\hline Run/expt. no. & $\begin{array}{l}\text { Response in terms of ethanol } \\
\text { titre }\left(\%, \mathrm{v} \mathrm{v}^{-1}\right)^{*}\end{array}$ & $S / N$ ratio \\
\hline 1 & $0.1527 \pm 0.05$ & -16.32 \\
\hline 2 & $0.1892 \pm 0.04$ & -14.46 \\
\hline 3 & $0.1427 \pm 0.09$ & -16.92 \\
\hline 4 & $0.1888 \pm 0.02$ & -14.48 \\
\hline 5 & $0.1828 \pm 0.07$ & -14.76 \\
\hline 6 & $0.1203 \pm 0.08$ & -18.39 \\
\hline 7 & $0.1874 \pm 0.06$ & -14.55 \\
\hline 8 & $0.2102 \pm 0.01$ & -13.55 \\
\hline 9 & $0.1837 \pm 0.03$ & -14.72 \\
\hline 10 & $0.2252 \pm 0.06$ & -12.95 \\
\hline 11 & $0.1910 \pm 0.05$ & -14.38 \\
\hline 12 & $0.1938 \pm 0.07$ & -14.26 \\
\hline 13 & $0.2093 \pm 0.08$ & -13.59 \\
\hline 14 & $0.1226 \pm 0.08$ & -18.23 \\
\hline 15 & $0.2170 \pm 0.04$ & -13.27 \\
\hline 16 & $0.2024 \pm 0.05$ & -13.87 \\
\hline 17 & $0.2006 \pm 0.03$ & -13.95 \\
\hline 18 & $0.2056 \pm 0.02$ & -13.74 \\
\hline 19 & $0.1245 \pm 0.01$ & -18.09 \\
\hline 20 & $0.2198 \pm 0.08$ & -13.16 \\
\hline 21 & $0.2170 \pm 0.09$ & -13.27 \\
\hline 22 & $0.2179 \pm 0.07$ & -13.24 \\
\hline 23 & $0.2512 \pm 0.03$ & -11.99 \\
\hline 24 & $0.2225 \pm 0.02$ & -13.05 \\
\hline 25 & $0.1267 \pm 0.05$ & -17.94 \\
\hline
\end{tabular}

${ }^{*}$ The values correspond to the maximum ethanol at a particular time; values are mean $\pm \operatorname{SE}(n=3)$.

ethanol production ranging from $0.120\left(\%, \mathrm{v} \mathrm{v}^{-1}\right)$ to 0.251 (\%, $\mathrm{v} \mathrm{v}^{-1}$ ) corresponding to the combined effect of the six factors in their specific ranges. The experimental results suggest that these factors at optimum level strongly support the production of ethanol. In run (expt. 6), with a combination of recombinant GH5 cellulase volume $(0.25 \mathrm{~mL})$, recombinant GH43 hemicellulase volume $(0.25 \mathrm{~mL}), S$. cerevisiae inoculum volume $(0.25 \mathrm{~mL})$, C. shehatae inoculum volume $(0.25 \mathrm{~mL}), \mathrm{pH}(3)$, and temperature $\left(26^{\circ} \mathrm{C}\right)$, an ethanol concentration of $0.120\left(\%, \mathrm{vv}^{-1}\right)$ was observed (Table 4, Figure 2). A maximum ethanol titre of $0.251\left(\%, \mathrm{vv}^{-1}\right)$ ethanol was observed in run (expt. 23) with a combination of recombinant GH5 cellulase volume $(1.0 \mathrm{~mL})$, recombinant GH43 hemicellulase volume $(0.5 \mathrm{~mL})$, S. cerevisiae inoculum volume $(1.50 \mathrm{~mL}), C$. shehatae inoculum volume $(0.25 \mathrm{~mL})$, $\mathrm{pH}(5)$, and temperature $\left(30^{\circ} \mathrm{C}\right)$ with the best response and maximum $S / N$ ratio (-11.99) (Table 4, Figure 2).

The Taguchi optimized fermentation process parameters are shown in Figure 3. The best process parameters in $100 \mathrm{~mL}$ of fermentation medium comprised $1.0 \mathrm{~mL}$ of recombinant GH5 cellulase $\left(5.7 \mathrm{U} \mathrm{mg}^{-1}, 0.45 \mathrm{mg} \mathrm{mL}^{-1}\right)$,

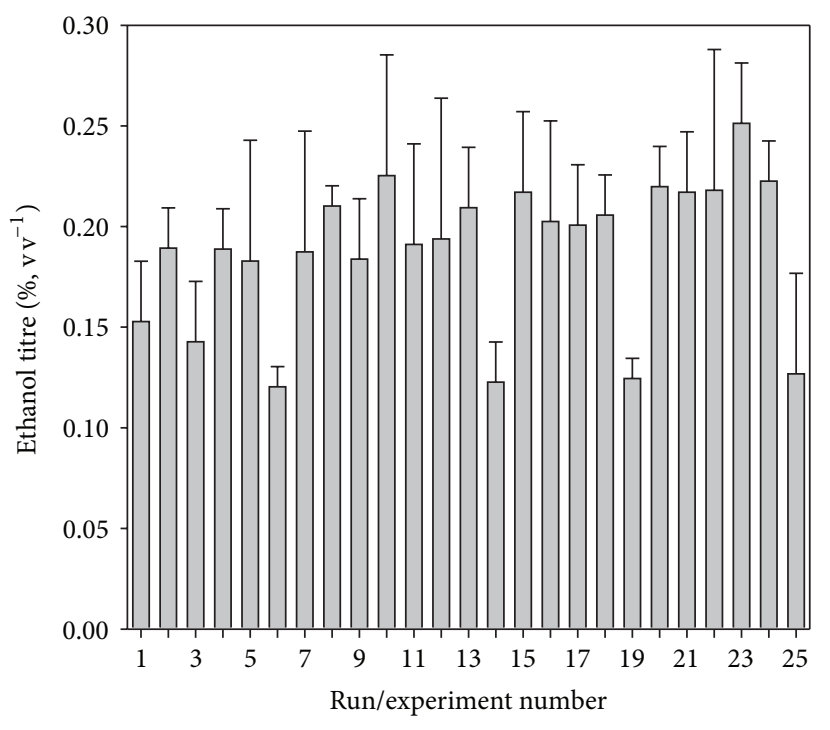

Figure 2: Comparative results of response in terms of ethanol titre $\left(\%, \mathrm{vv}^{-1}\right)$ of Taguchi $\mathrm{L}_{25}$ orthogonal array of experiments.

$2.0 \mathrm{~mL}$ of recombinant $\mathrm{GH} 43$ hemicellulase $\left(3.7 \mathrm{U} \mathrm{mg}^{-1}\right.$, $\left.0.32 \mathrm{mg} \mathrm{mL}^{-1}\right), 1.5 \mathrm{~mL}$ of $S$. cerevisiae $\left(3.9 \times 10^{8}\right.$ cells mL $\left.{ }^{-1}\right)$, $0.25 \mathrm{~mL}$ of $C$. shehatae $\left(2.7 \times 10^{7}\right.$ cells $\left.\mathrm{mL}^{-1}\right), \mathrm{pH}$ of 4.3 , and temperature of $35^{\circ} \mathrm{C}$.

The analysis of variance (ANOVA) for the responses of ethanol production was carried out according to the factors' contribution by the Taguchi method (Table 5). From the calculated ratios $(F)$, it can be inferred that the factors considered in the experimental design are statistically significant at $95 \%$ confidence limit. Table 6 represented the contribution of the selected factors to bioethanol production. It can be observed that, on the basis of $p$-value $(p<0.05), \mathrm{pH}$ with rank 1 is the most significant of all other factors and shows the highest positive impact on the ethanol production. C. shehatae inoculum volume showed the least impact on ethanol production among the factors studied with the assigned variance of values. Several scientists have reported that the transport of chemical products and enzymes across the cell membrane is affected by the $\mathrm{pH}$ of the fermentation medium, influencing many enzymatic reactions [28]. The statistical outcomes in our research also confirmed fermentation medium $\mathrm{pH}$ to be an important factor affecting SSF. Similar findings have been reported in the literature [9]. C. shehatae inoculum volume showed the least impact among the factors studied with the assigned variance of values.

3.3. Validation of Taguchi Experimental Model. The validation of Taguchi experimental model is represented in Table 7. It was observed that the response (ethanol $\%, \mathrm{vv}^{-1}$ ) $(0.254)$ as well as $S / N$ ratio $(-10.95)$ for Taguchi optimum values was more than the experimental optimum values for ethanol production $\left(0.2512 \%, \mathrm{vv}^{-1}\right)$ and $S / N$ ratio $(-11.99)$ (Table 7). This validated the Taguchi optimized SSF process parameters. Thus, there was a 1.3-fold increase in ethanol titre with Taguchi optimized SSF process parameters as compared 

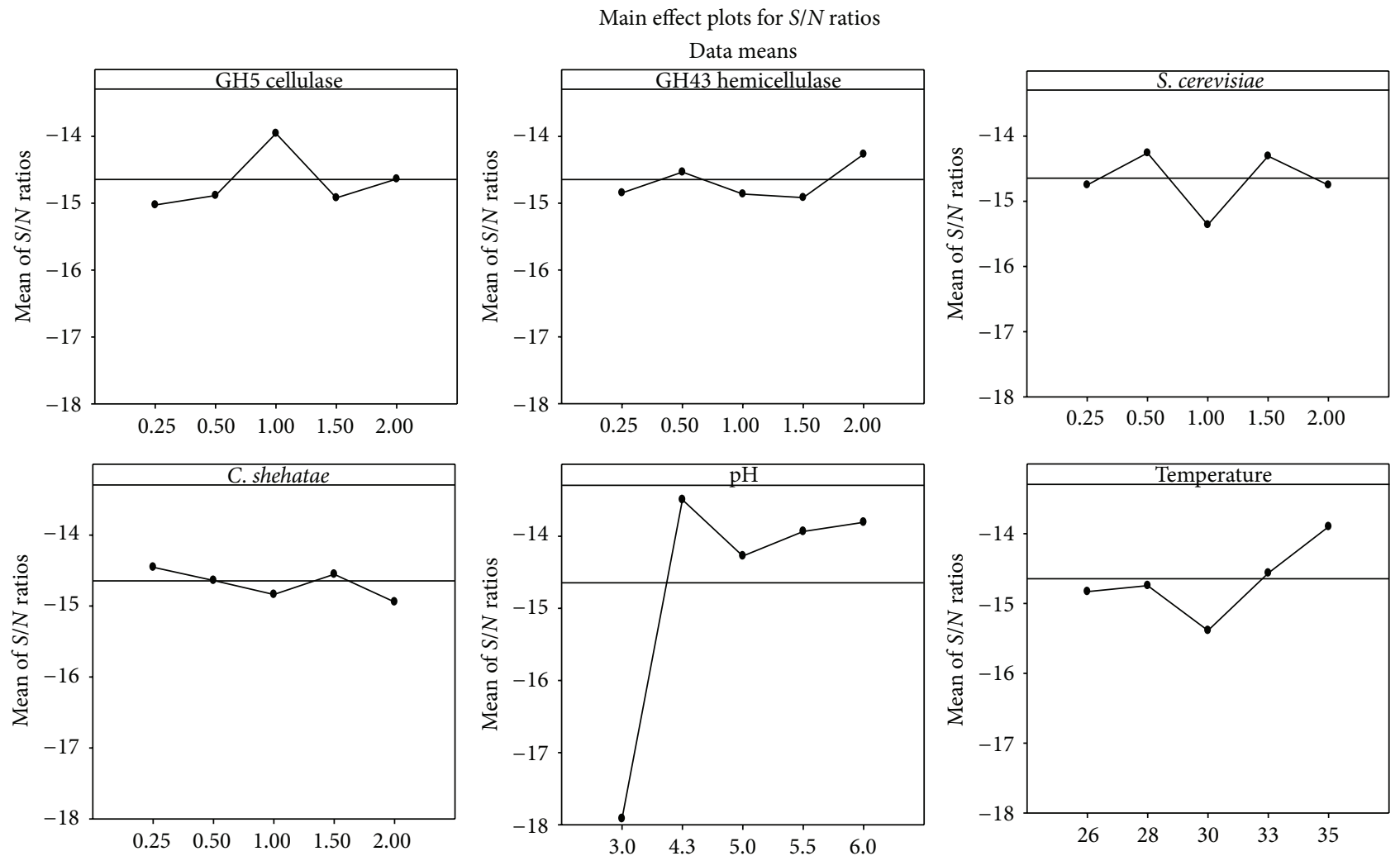

Signal-to-noise: larger is better

FIGURE 3: Main effect plots for $S / N$ ratios with larger-the-better objective function of Taguchi optimized fermentation process parameters.

TABLE 5: Analysis of variance for the responses of ethanol production.

\begin{tabular}{|c|c|c|c|c|c|c|}
\hline Source & $\mathrm{DF}$ & Seq. SS & Adj. SS & Adj. MS & $F$ & $p$ \\
\hline Recombinant GH5 cellulase & 1 & 0.0000660 & 0.0000660 & 0.0000660 & 0.08 & 0.783 \\
\hline Recombinant GH43 hemicellulase & 1 & 0.0000637 & 0.0000637 & 0.0000637 & 0.08 & 0.786 \\
\hline S. cerevisiae & 1 & 0.0000000 & 0.0000000 & 0.0000000 & 0.00 & 0.996 \\
\hline C. shehatae & 1 & 0.0002732 & 0.0002732 & 0.0002732 & 0.32 & 0.576 \\
\hline $\mathrm{pH}$ & 1 & 0.0150152 & 0.0150152 & 0.0150152 & 17.85 & 0.001 \\
\hline Temp & 1 & 0.0012587 & 0.0012587 & 0.0012587 & 1.50 & 0.237 \\
\hline Error & 18 & 0.0151394 & 0.0151394 & 0.0008411 & & \\
\hline Total & 24 & 0.0318162 & & & & \\
\hline
\end{tabular}

DF: degrees of freedom, SS: sum of squares, and MS: mean of squares.

to unoptimized parameters (Table 3). These experiments supported the analysis of the main effect of each constituent of the medium. The Taguchi SSF experiments provided basic information for the improvement of the ethanol production efficiency. Finally, using the Taguchi optimized fermentation process parameters (Table 7), the SSF process was scaled up at bioreactor level.

3.4. Scale-Up of Taguchi Optimized Simultaneous Saccharification and Fermentation (SSF) Process Parameters Involving Mixed Pretreated 1\% $\left(w v^{-1}\right)$ Wild Grass at Bioreactor Level. It is a well-established fact that the fermentation dynamics and, in turn, the final ethanol titre are significantly affected by the parameters, namely, $\mathrm{pH}$ and aeration [29]. The SSF process involving statistically designed Taguchi optimized fermentation process parameters and mixed pretreated $1 \%$ $\left(\mathrm{wv}^{-1}\right)$ wild grass was finally scaled up in an automated bioreactor enabling the stringent monitoring of important process parameters (Figure 4).

$S$. cerevisiae and $C$. shehatae remained in a very short lag phase of initial $6 \mathrm{~h}$ and displayed an exponential growth profile (Figure 4). Until the $66 \mathrm{~h}$, the biomass concentration increased considerably as the organisms entered the log phase reaching a maximum cell OD $\left(\mathrm{A}_{600 \mathrm{~nm}}\right)$ of 1.4 , and, finally, a decline phase was observed thereafter. A biphasic 
TABLE 6: Rank and significance of various factors.

\begin{tabular}{|c|c|c|}
\hline Factor/parameter & Rank & $p$-value \\
\hline $\begin{array}{l}\text { Recombinant GH5 cellulase } \\
\left(5.7 \mathrm{U} \mathrm{mg}^{-1}, 0.45 \mathrm{mg} \mathrm{mL}^{-1}\right)\end{array}$ & 4 & 0.783 \\
\hline $\begin{array}{l}\text { Recombinant GH43 hemicellulase* } \\
\left(3.7 \mathrm{U} \mathrm{mg}^{-1}, 0.32 \mathrm{mg} \mathrm{mL}^{-1}\right)\end{array}$ & 5 & 0.786 \\
\hline S. cerevisiae ${ }^{*}\left(3.6 \times 10^{8}\right.$ cells $\left.\mathrm{mL}^{-1}\right)$ & 3 & 0.996 \\
\hline C. shehatae ${ }^{*}\left(2.1 \times 10^{8}\right.$ cells $\left.\mathrm{mL}^{-1}\right)$ & 6 & 0.576 \\
\hline $\mathrm{pH}$ & 1 & 0.001 \\
\hline Temperature & 2 & 0.237 \\
\hline
\end{tabular}

$p<0.05$.

TABLE 7: Validation of Taguchi experimental data values.

\begin{tabular}{|c|c|c|}
\hline Factor/parameter & $\begin{array}{c}\text { Taguchi } \\
\text { optimum }\end{array}$ & $\begin{array}{c}\text { Experiment } \\
\text { optimum }\end{array}$ \\
\hline $\begin{array}{l}\text { Recombinant GH5 cellulase } \\
\left(5.7 \mathrm{U} \mathrm{mg}^{-1}, 0.45 \mathrm{mg} \mathrm{mL}^{-1}\right)\left(\%, \mathrm{vv}^{-1}\right)\end{array}$ & 1.0 & 1.0 \\
\hline $\begin{array}{l}\text { Recombinant GH43 hemicellulase } \\
\left(3.7 \mathrm{U} \mathrm{mg}^{-1}, 0.32 \mathrm{mg} \mathrm{mL}^{-1}\right)\left(\%, \mathrm{vv}^{-1}\right)\end{array}$ & 2.0 & 0.5 \\
\hline $\begin{array}{l}\text { S. cerevisiae }\left(3.6 \times 10^{8} \text { cells } \mathrm{mL}^{-1}\right) \\
\left(\%, \mathrm{vv}^{-1}\right)\end{array}$ & 1.5 & 1.5 \\
\hline $\begin{array}{l}\text { C. shehatae }\left(2.1 \times 10^{8} \text { cells } \mathrm{mL}^{-1}\right) \\
\left(\%, \mathrm{vv}^{-1}\right)\end{array}$ & 0.25 & 0.25 \\
\hline $\mathrm{pH}$ & 4.3 & 5.0 \\
\hline Temperature $\left({ }^{\circ} \mathrm{C}\right)$ & 35 & 35 \\
\hline$S / N$ ratio & -10.95 & -11.99 \\
\hline $\begin{array}{l}\text { Response experimental } \\
\text { ethanol titre }\left(\%, \mathrm{vv}^{-1}\right)\end{array}$ & 0.2540 & 0.2512 \\
\hline $\begin{array}{l}\text { Response predicted }\left(\%, \mathrm{vv}^{-1}\right) \\
\text { ethanol titre }\left(\%, \mathrm{vv}^{-1}\right)\end{array}$ & 0.2705 & 0.2677 \\
\hline Ethanol titre $\left(\mathrm{g} \mathrm{L}^{-1}\right)$ & 2.00 & 1.98 \\
\hline $\begin{array}{l}\text { Ethanol yield } \\
\text { ( } g \text { of ethanol } g \text { of substrate }{ }^{-1} \text { ) }\end{array}$ & 0.200 & 0.198 \\
\hline
\end{tabular}

ethanol formation was recorded. The initial phase of ethanol production documented a titre of $2.25 \mathrm{~g} \mathrm{~L}^{-1}$ at $18 \mathrm{~h}$ of SSF followed by a slight decrease in ethanol synthesis rate till $36 \mathrm{~h}$. The final phase of ethanol kinetics witnessed a maximum ethanol concentration of $3.10 \mathrm{~g} \mathrm{~L}^{-1}$ (Figure 4) with an ethanol yield of 0.472 ( $\mathrm{g}$ of ethanol $\mathrm{g}$ of substrate ${ }^{-1}$ ) at $66 \mathrm{~h}$ and then a declination in ethanol titre was observed till the end of the fermentation process (Table 3, Figure 4). The reducing sugar concentration peaked during the initial $18 \mathrm{~h}$ of fermentation reaching a maximum concentration of $4.02 \mathrm{gL}^{-1}$ (Table 3 , Figure 4). As A. hymenoides have more cellulosic content, the dynamic profile of only recombinant GH5 cellulase has been presented in Figure 4. The activities of mixed enzymatic consortium decreased with the progress of SSF. The drop in reducing sugar concentration after $18 \mathrm{~h}$ clearly indicated the sugar uptake by the hexose and pentose utilizing microbes for their growth, maintenance, and ethanol production.

The controlled parameters of $\mathrm{pH}$ and aeration rate significantly affected the growth and ethanol concentration. A threshold dissolved oxygen (DO) level of minimum $40 \%$ was

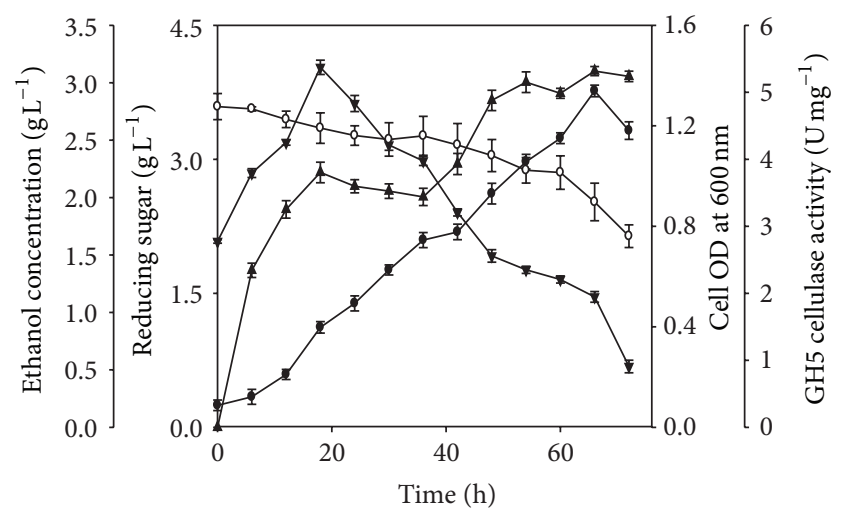

FIGURE 4: SSF profile of $1 \%\left(\mathrm{wv}^{-1}\right)$ mixed MAA and organosolv pretreated wild grass (Achnatherum hymenoides) using statistically designed Taguchi optimized fermentation process parameters, namely, recombinant cellulase (GH5), recombinant hemicellulase (GH43) along with S. cerevisiae, C. shehatae, $\mathrm{pH}$, and temperature, at bioreactor level showing variation of $(\bullet)$ cell OD measured at $600 \mathrm{~nm},(\boldsymbol{\Delta})$ ethanol concentration $\left(\mathrm{g} \mathrm{L}^{-1}\right),(\boldsymbol{\nabla})$ reducing sugar $\left(\mathrm{g} \mathrm{L}^{-1}\right)$, and $(\mathrm{O})$ specific activity $\left(\mathrm{U} \mathrm{mg}^{-1}\right)$ of $\mathrm{GH} 5$ cellulase with time (h). Similar specific activity profiles were obtained for recombinant hemicellulase (GH43) (data not shown).

maintained by $1 \mathrm{vvm}$ aeration rate for the efficient growth of bioethanol producers and, in turn, a good product yield. The ethanol titre obtained in Taguchi optimized shake flask SSF was $2.0 \mathrm{~g} \mathrm{~L}^{-1}$ (Table 3) implying a 1.3-fold rise as compared to ethanol titre of $1.5 \mathrm{~g} \mathrm{~L}^{-1}$ (Table 3) in unoptimized shake flask SSF. A 1.5-fold upsurge in ethanol titre $\left(3.1 \mathrm{~g} \mathrm{~L}^{-1}\right)$ (Table 3) was obtained in lab scale bioreactor on scaling up the shake flask SSF $\left(2.0 \mathrm{~g} \mathrm{~L}^{-1}\right)$ (Table 3 ) with Taguchi optimized SSF process parameters. The dynamic profiles of various offline measurements from various SSF batch runs established a complex interplay between the rates of saccharification by the mixed recombinant enzymes, utilization of sugar by bioethanol producers, and finally the formation of ethanol. The reducing sugar profile was inversely proportional to the rate of ethanol formation. The repressed enzyme activities in the later stages of fermentation might be attributed to sugar accumulation in the broth. A depleted reducing sugar concentration was observed without any further upturn in ethanol titre during the late log phase indicating the sugars utilization only for maintenance and endurance of the fermentative microbes.

The ethanol titre values obtained in our research are comparable with the findings reported in the literature. An ethanol titre of $2.1 \mathrm{~g} \mathrm{~L}^{-1}$ has been reported from $1 \%$ $\left(\mathrm{w} \mathrm{v}^{-1}\right)$ mango leaves with recombinant GH43 hemicellulase from C. thermocellum and C. shehatae [3]. The coculture of C. thermosaccharolyticum HG8 and Thermoanaerobacter ethanolicus ATCC 31937 provided an ethanol concentration $\left(2.2 \mathrm{~g} \mathrm{~L}^{-1}\right)$ from $1 \%\left(\mathrm{w} \mathrm{v}^{-1}\right)$ of banana waste [30]. The recombinant cellulase from Clostridium thermocellum offered an ethanol titre of $1.4 \mathrm{~g} \mathrm{~L}^{-1}$ from $1 \%\left(\mathrm{w} \mathrm{v}^{-1}\right)$ Jamun (Syzygium cumini) leafy biomass [31]. A SSF process from $6 \%\left(\mathrm{w} \mathrm{w}^{-1}\right)$ solka floc employing commercial cellulase and Kluyveromyces 
marxianus contributed to an ethanol yield of $0.337\left(\mathrm{gg}^{-1}\right)$ [27]. An ethanol titre of $1 \mathrm{~g} \mathrm{~L}^{-1}$ from $1 \%\left(\mathrm{w} \mathrm{v}^{-1}\right)$ wheat straw using crude unprocessed Trichoderma reesei cellulase has been reported [32].

\section{Conclusions}

This study reported for the first time the statistical optimization and validation of different fermentation process parameters for bioethanol production from mixed MAA and organosolv pretreated $1 \%\left(\mathrm{wv}^{-1}\right)$ wild grass using Taguchi orthogonal array design, namely, mixed recombinant $C$. thermocellum hydrolytic enzymes' volume along with mixed fermentative microbes' inoculum volume, $\mathrm{pH}$, and temperature. The model was successfully validated at shake flask level with $\mathrm{pH}$ as the most significant factor. Finally, the optimized process parameters were scaled up at bioreactor level with a gain of significant ethanol titre. In essence, the statistical optimization of fermentation process parameters involving recombinant enzymes can transform the weed, $A$. hymenoides, into the fuel of tomorrow, bioethanol.

\section{Conflict of Interests}

The authors clearly state that they do not have any possible conflict of interests with the mentioned commercial identities.

\section{Acknowledgments}

Mr. Saprativ P. Das is supported by Ph.D. fellowship from the Indian Institute of Technology Guwahati through Ministry of Human Resource and Development (MHRD), Government of India, New Delhi, India. The research work in part is supported by a project Grant (BT/23/NE/TBP/2010) from Department of Biotechnology (DBT), Ministry of Science and Technology, New Delhi, India, to Arun Goyal.

\section{References}

[1] Y. Sun and J. Cheng, "Hydrolysis of lignocellulosic materials for ethanol production: a review," Bioresource Technology, vol. 83, no. 1, pp. 1-11, 2002.

[2] M. Ballesteros, J. M. Oliva, M. J. Negro, P. Manzanares, and I. Ballesteros, "Ethanol from lignocellulosic materials by a simultaneous saccharification and fermentation process (SFS) with Kluyveromyces marxianus CECT 10875," Process Biochemistry, vol. 39, no. 12, pp. 1843-1848, 2004.

[3] S. P. Das, R. Ravindran, S. Ahmed et al., "Bioethanol production involving recombinant $C$. thermocellum hydrolytic hemicellulase and fermentative microbes," Applied Biochemistry and Biotechnology, vol. 167, pp. 1475-1488, 2012.

[4] A. L. Demain, M. Newcomb, and J. H. D. Wu, "Cellulase, clostridia, and ethanol," Microbiology and Molecular Biology Reviews, vol. 69, no. 1, pp. 124-154, 2005.

[5] N. Adlakha, R. Rajagopal, S. Kumar, V. S. Reddy, and S. S. Yazdani, "Synthesis and characterization of chimeric proteins based on cellulase and xylanase from an insect gut bacterium,"
Applied and Environmental Microbiology, vol. 77, no. 14, pp. 4859-4866, 2011.

[6] P. Kumar, D. M. Barrett, M. J. Delwiche, and P. Stroeve, "Methods for pretreatment of lignocellulosic biomass for efficient hydrolysis and biofuel production," Industrial and Engineering Chemistry Research, vol. 48, no. 8, pp. 3713-3729, 2009.

[7] K. Grohmann, E. A. Baldwin, and B. S. Buslig, "Production of ethanol from enzymatically hydrolyzed orange peel by the yeast Saccharomyces cerevisiae," Applied Biochemistry and Biotechnology, vol. 45-46, no. 1, pp. 315-327, 1994.

[8] A. K. Chandel, R. K. Kapoor, A. Singh, and R. C. Kuhad, "Detoxification of sugarcane bagasse hydrolysate improves ethanol production by Candida shehatae NCIM 3501," Bioresource Technology, vol. 98, no. 10, pp. 1947-1950, 2007.

[9] M. Latifian, Z. Hamidi-Esfahani, and M. Barzegar, "Evaluation of culture conditions for cellulase production by two Trichoderma reesei mutants under solid-state fermentation conditions," Bioresource Technology, vol. 98, no. 18, pp. 36343637, 2007.

[10] K. S. Vishwanatha, A. G. A. Rao, and S. A. Singh, "Acid protease production by solid-state fermentation using Aspergillus oryzae MTCC 5341: optimization of process parameters," Journal of Industrial Microbiology and Biotechnology, vol. 37, no. 2, pp. 129138,2010

[11] J. Antony, M. Kaye, and A. Frangou, "A strategic methodology to the use of advanced statistical quality improvement techniques," TQM Magazine, vol. 10, no. 3, pp. 169-176, 1998.

[12] D. H. Stamatis, TQM Engineering Handbook, Marcel Dekker, New York, NY, USA, 1977.

[13] G. Taguchi, Introduction to Quality Engineering, UNIPUB/Kraus International, White Plains, NY, USA, 1986.

[14] D. M. Byrne and S. Taguchi, "The Taguchi approach to parameter design," Quality Progress, vol. 20, no. 12, pp. 19-26, 1987.

[15] D. De Oliveira and T. L. M. Alves, "A kinetic study of lipasecatalyzed alcoholysis of palm kernel oil," Applied Biochemistry and Biotechnology A, vol. 84-86, pp. 59-68, 2000.

[16] E. J. Taylor, A. Goyal, C. I. P. D. Guerreiro et al., "How family 26 glycoside hydrolases orchestrate catalysis on different polysaccharides: structure and activity of a Clostridium thermocellum lichenase, CtLic26A," The Journal of Biological Chemistry, vol. 280, no. 38, pp. 32761-32767, 2005.

[17] S. Bharali, R. K. Purama, A. Majumder, C. M. G. A. Fontes, and A. Goyal, "Molecular cloning and biochemical properties of family 5 glycoside hydrolase of bi-functional cellulase from Clostridium thermocellum," Indian Journal of Microbiology, vol. 45, no. 4, pp. 317-321, 2005.

[18] L. J. Wickerman, Taxonomy of Yeasts, US Department of Agriculture Technical Bulletin, Washington, DC, USA, 1951.

[19] S. Zhu, Y. Wu, Z. Yu et al., "Production of ethanol from microwave-assisted alkali pretreated wheat straw," Process Biochemistry, vol. 41, no. 4, pp. 869-873, 2006.

[20] A. Geng, F. Xin, and J.-Y. Ip, "Ethanol production from horticultural waste treated by a modified organosolv method," Bioresource Technology, vol. 104, no. 7, pp. 715-721, 2012.

[21] A. Sluiter, B. Hames, R. Ruiz et al., "Determination of structural carbohydrates and lignin in substrates," Tech. Rep. NREL/TP510, Laboratory Analytical Procedure (LAP), Boulder, Colo, USA, 2008.

[22] N. Nelson, "A photometric adaptation of the Somogyi method for the determination of glucose," The Journal of Biological Chemistry, vol. 153, pp. 375-380, 1944. 
[23] M. Somogyi, "Determination of blood sugar," The Journal of Biological Chemistry, vol. 160, pp. 69-73, 1945.

[24] M. M. Bradford, "A rapid and sensitive method for the quantitation of microgram quantities of protein utilizing the principle of protein dye binding," Analytical Biochemistry, vol. 72, no. 1-2, pp. 248-254, 1976.

[25] V. V. R. Bandaru, S. R. Somalanka, D. R. Mendu, N. R. Madicherla, and A. Chityala, "Optimization of fermentation conditions for the production of ethanol from sago starch by coimmobilized amyloglucosidase and cells of Zymomonas mobilis using response surface methodology," Enzyme and Microbial Technology, vol. 38, no. 1-2, pp. 209-214, 2006.

[26] H.-B. Seo, H.-J. Kim, O.-K. Lee, J.-H. Ha, H.-Y. Lee, and K.H. Jung, "Measurement of ethanol concentration using solvent extraction and dichromate oxidation and its application to bioethanol production process," Journal of Industrial Microbiology and Biotechnology, vol. 36, no. 2, pp. 285-292, 2009.

[27] Z. Kádár, Z. Szengyel, and K. Réczey, "Simultaneous saccharification and fermentation (SSF) of industrial wastes for the production of ethanol," Industrial Crops and Products, vol. 20, no. 1, pp. 103-110, 2004.

[28] Y. Liang, Z. Feng, J. Yesuf, and J. W. Blackburn, “Optimization of growth medium and enzyme assay conditions for crude cellulases produced by a novel thermophilic and cellulolytic bacterium, Anoxybacillus sp.", Applied Biochemistry and Biotechnology, vol. 160, no. 6, pp. 1841-1852, 2010.

[29] S. Sánchez, V. Bravo, E. Castro, A. J. Moya, and F. Camacho, “The influence of $\mathrm{pH}$ and aeration rate on the fermentation of Dxylose by Candida shehatae," Enzyme and Microbial Technology, vol. 21, no. 5, pp. 355-360, 1997.

[30] Y. Harish Kumar Reddy, M. Srijana, D. Madhusudhan Reddy, and R. Gopal, "Coculture fermentation of banana agro-waste to ethanol by cellulolytic thermophilic Clostridium thermocellum CT2," African Journal of Biotechnology, vol. 9, no. 13, pp. 19261934, 2010.

[31] R. Mutreja, D. Das, D. Goyal, and A. Goyal, "Bioconversion of agricultural waste to ethanol by SSF using recombinant cellulase from Clostridium thermocellum," Enzyme Research, vol. 2011, Article ID 340279, 6 pages, 2011.

[32] M. Lever, G. Ho, and R. Cord-Ruwisch, "Ethanol from lignocellulose using crude unprocessed cellulase from solid-state fermentation," Bioresource Technology, vol.101, no. 18, pp. 70947098, 2010. 


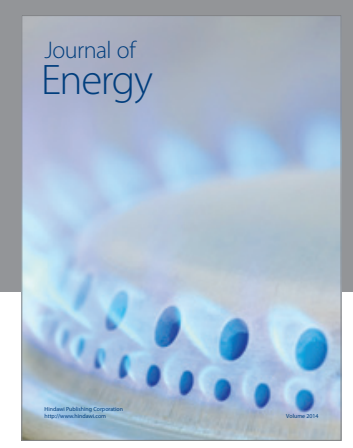

Journal of

Industrial Engineering
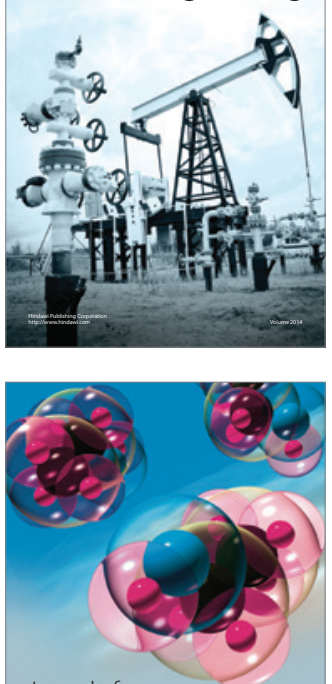

Fuels
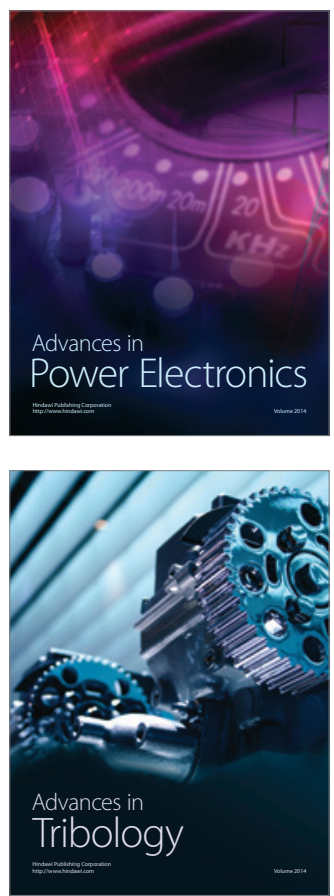

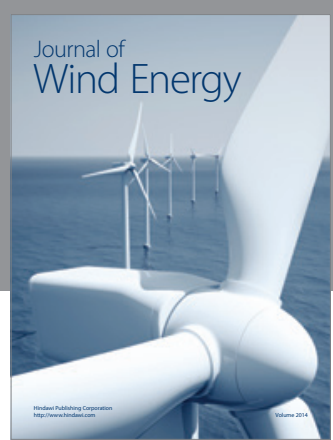

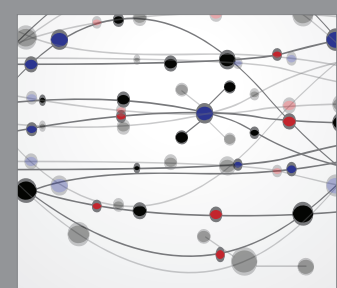

The Scientific World Journal

Submit your manuscripts at http://www.hindawi.com

Journal of

Structures
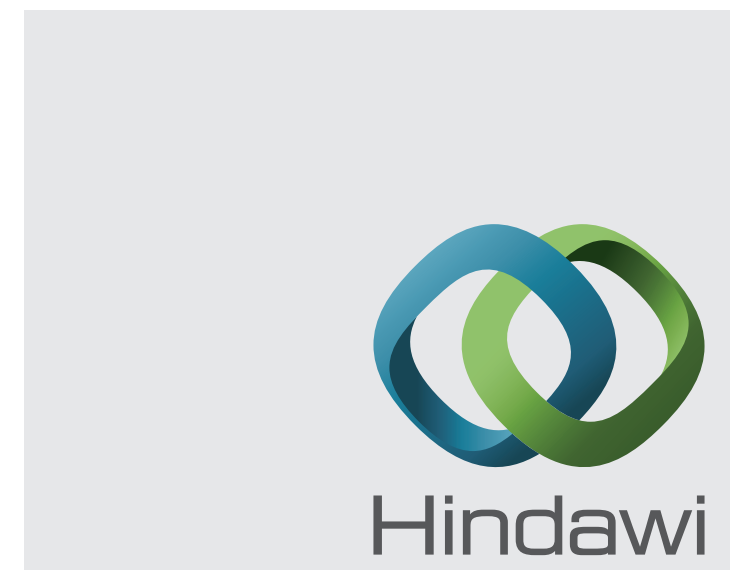

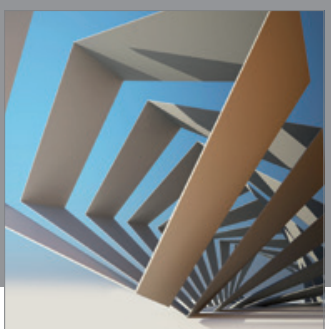

Rotating

Machinery
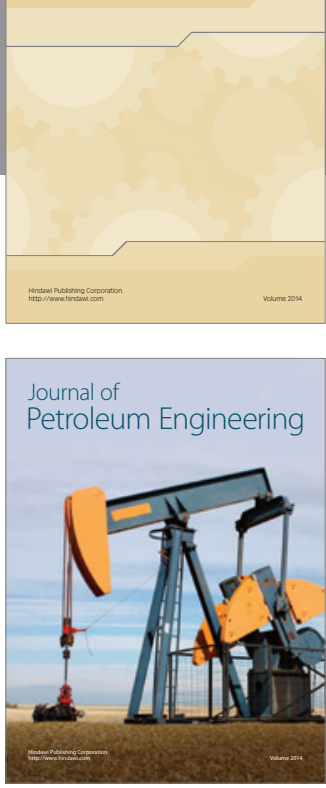

Journal of

Solar Energy
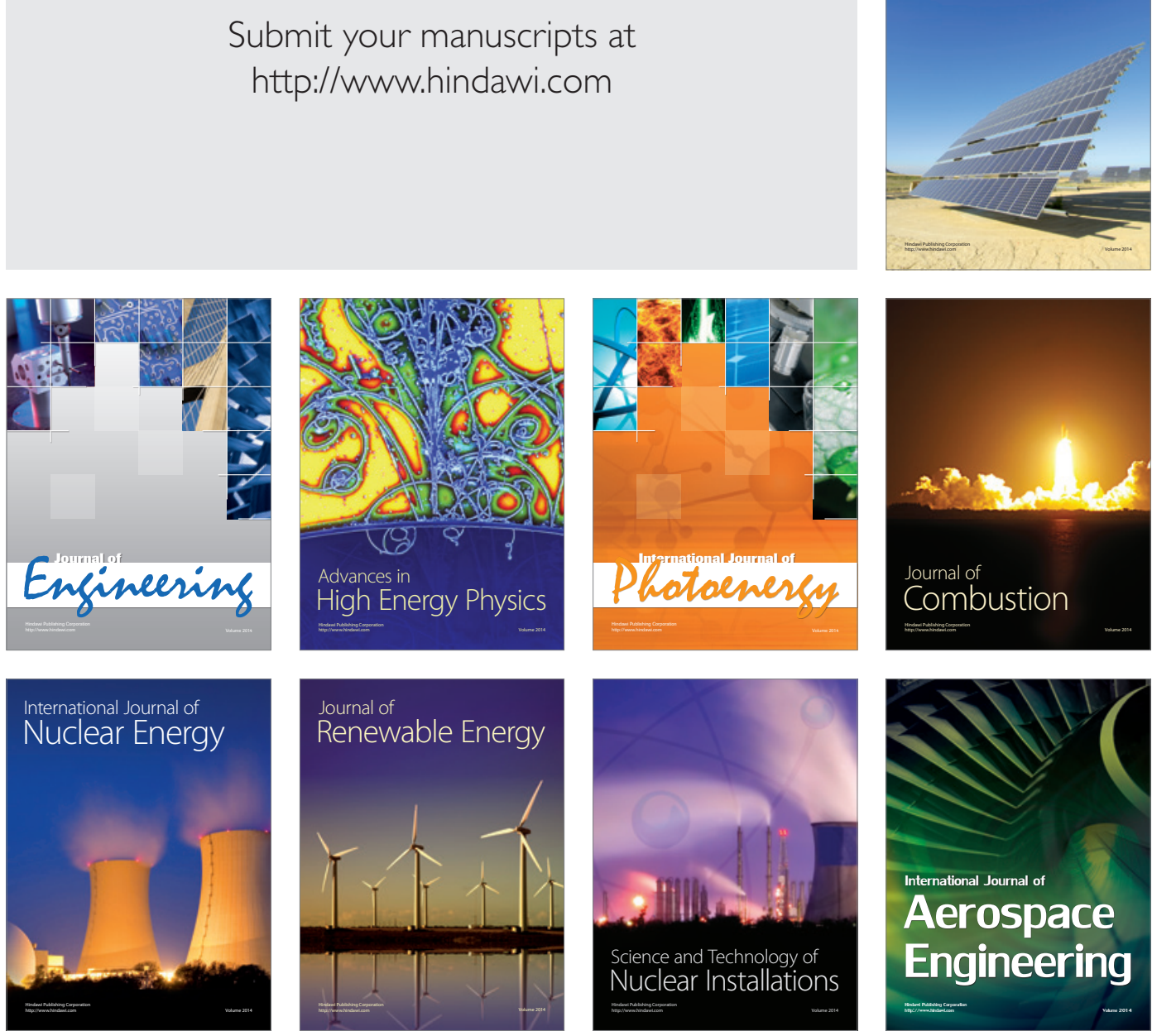